\title{
Presentación del caso
}

\author{
Dr. Juan Pablo Ghisi \\ Argus Diagnóstico Médico \\ Jefe del Servicio de Resonancia Magnética, Hospital General de Agudos “Dr. Juan A. Fernández”, Ciudad Autónoma de Buenos Aires, \\ Argentina

\section{Dr. Guillermo Schneebeli} \\ Especialista en Ortopedia y Traumatología \\ Jefe del Departamento Médico del Club Atlético Tigre, Buenos Aires, Argentina
}

\section{Dra. Agostina Lamanna}

Médica de Staff de Tomografía Computada y Resonancia Magnética, Sede San Miguel, Buenos Aires, Argentina Argus Diagnóstico Médico

Resolución del caso en la página 188.

Se describen tres casos con un cuadro y un tratamiento similares, pero con diferente evolución o imágenes de presentación. Todos los pacientes sufrieron ruptura del ligamento cruzado anterior (LCA) y fueron sometidos a ligamentoplastia utilizando la técnica de hueso-tendón rotuliano-hueso (HTH). En el control, tenían antecedentes de un nuevo episodio traumático. En esta primera parte, se muestra un caso. En la Discusión, se describirán los otros dos casos que tienen una presentación diferente por imágenes, con el propósito de efectuar una revisión del tema, haciendo hincapié en la valoración por resonancia magnética (RM).

Se trata de un paciente de 18 años que se había desgarrado el LCA y había sido tratado quirúrgicamente con HTH. Sufrió un nuevo episodio traumático con mecanismo en valgo practicando fútbol en césped sintético con botines de césped natural.

En el examen físico, se constató inestabilidad mediante las maniobras de Lachman y del pivot shift, por lo que se solicitó un control por RM.

\section{HALLAZGOS E INTERPRETACIÓN DE LOS ESTUDIOS POR IMÁGENES}

Las imágenes de la RM en el plano sagital, en el hueco intercondíleo muestran alteración difusa de señal. No se logra identificar estructura neoligamentaria como tal. Hay solución de continuidad proximal y las fibras visibles se observan horizontalizadas (Figuras 1-5). 


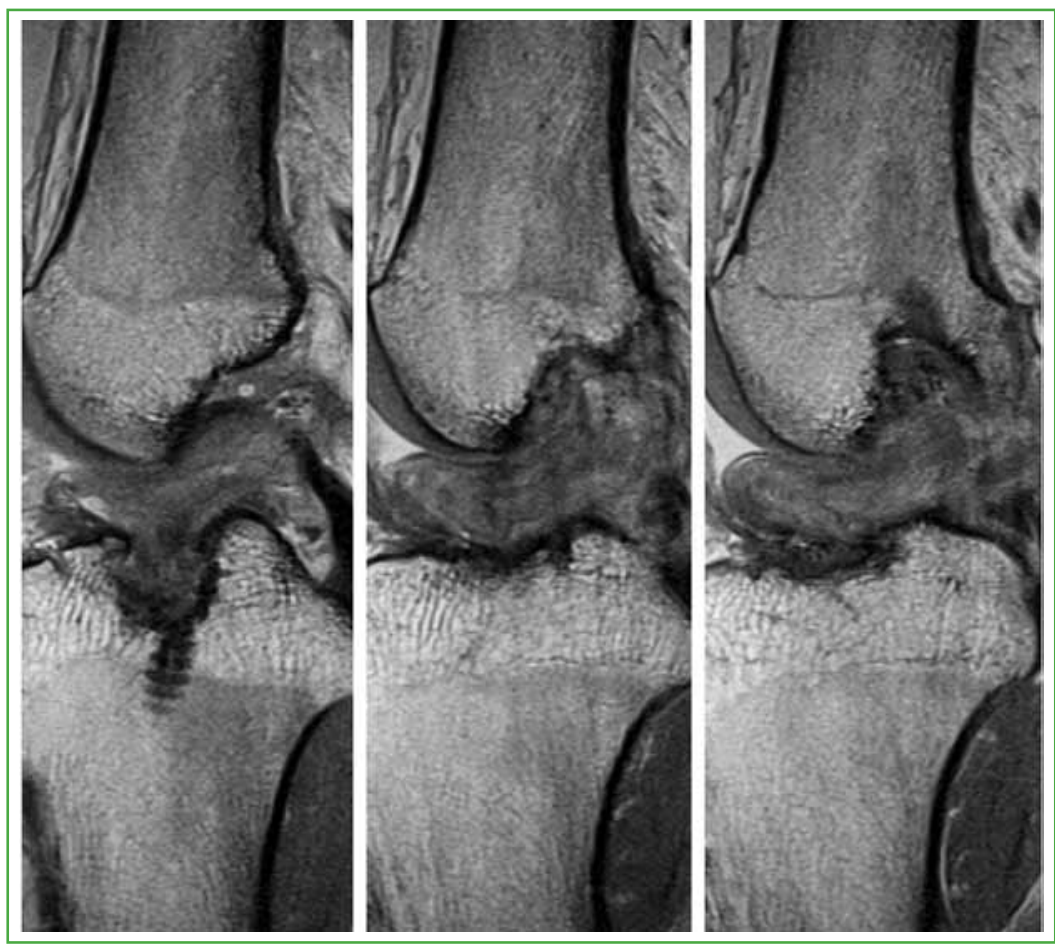

Figura 1. Resonancia magnética de rodilla en el plano sagital, con secuencia DP (3000/23). Alteración difusa de la señal en el hueco intercondíleo, sin que se pueda identificar claramente el neoligamento.

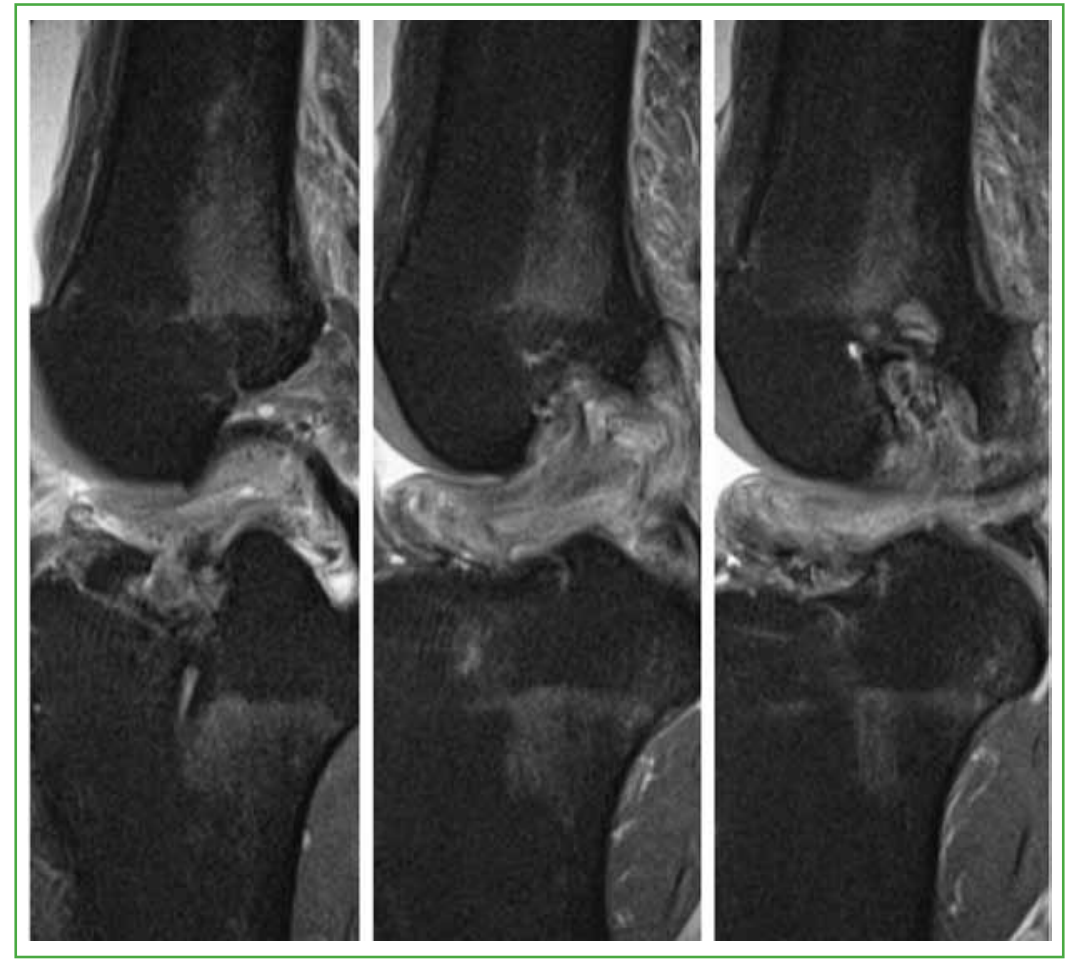

Figura 2. Resonancia magnética de rodilla en el plano sagital, con secuencia DP con supresión grasa (3050/31). Discontinuidad de fibras en el sector proximal con horizontalización de fibras distales del injerto. 


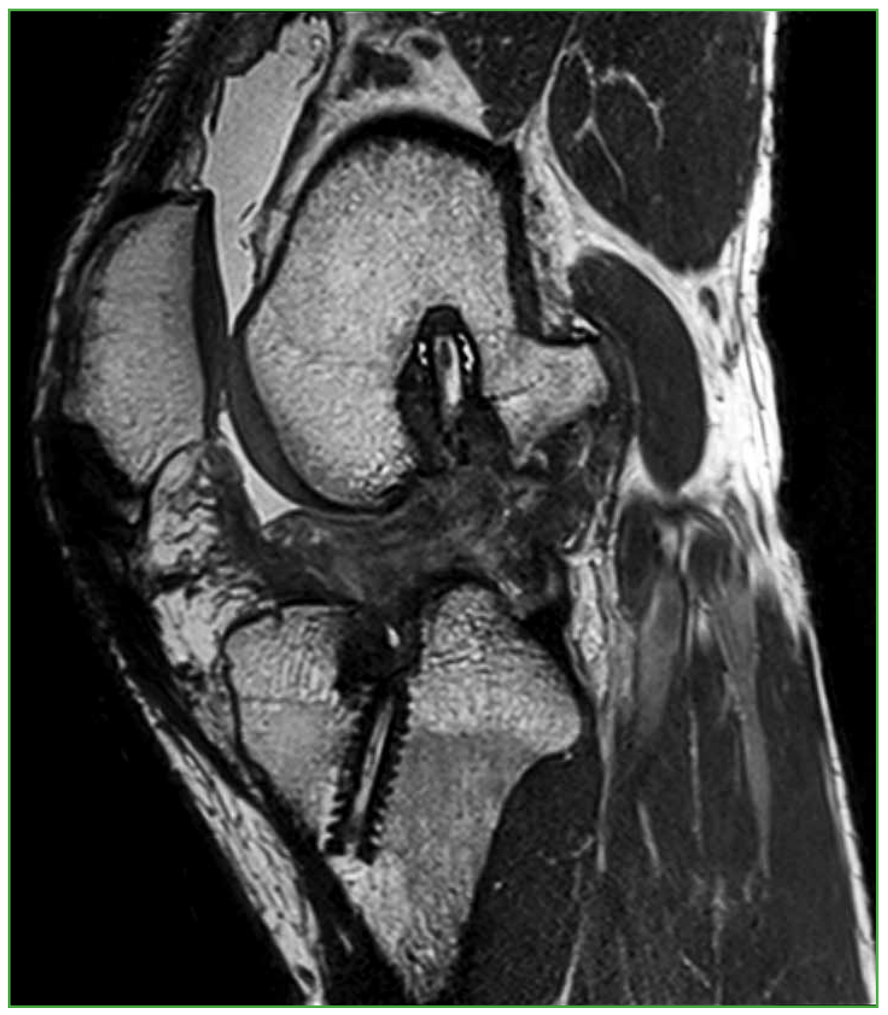

Figura 3. Resonancia magnética con secuencia spc T2 3D volumétrica (1200/39) con reconstrucción MPR en el plano sagital oblicuo uniendo ambos túneles. Discontinuidad de fibras sin identificar claramente el injerto.

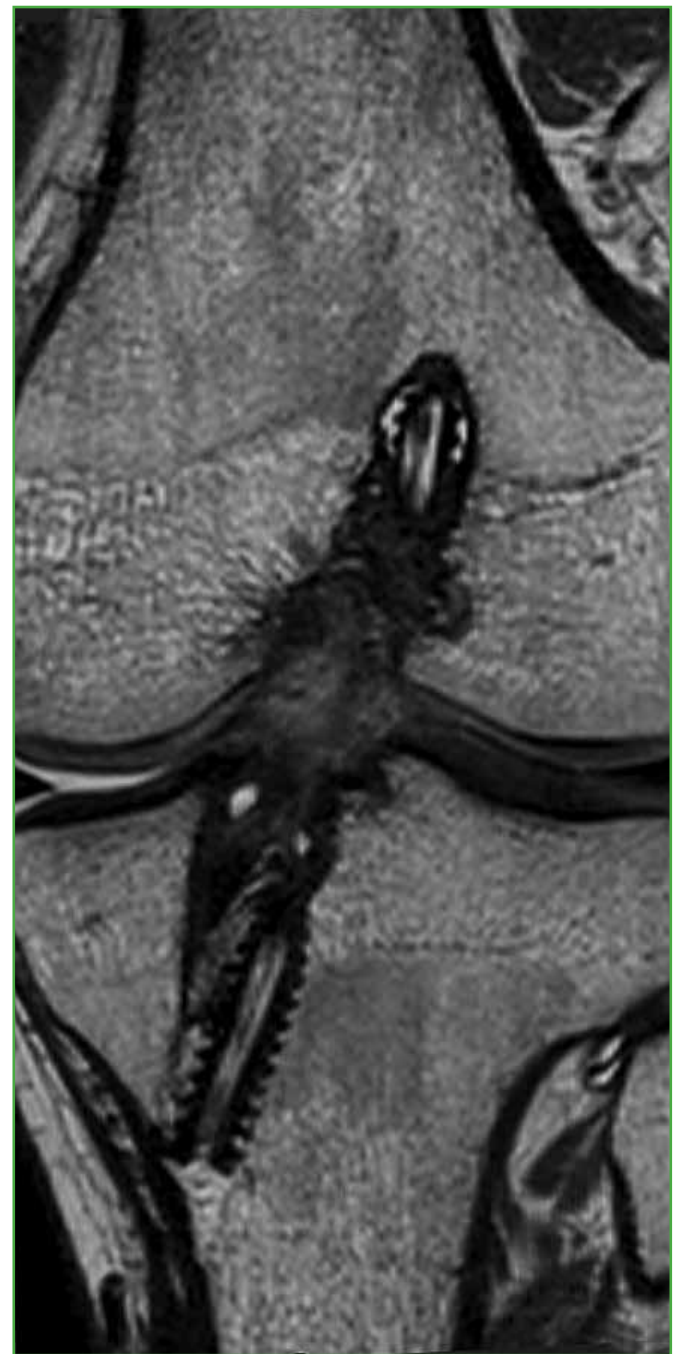




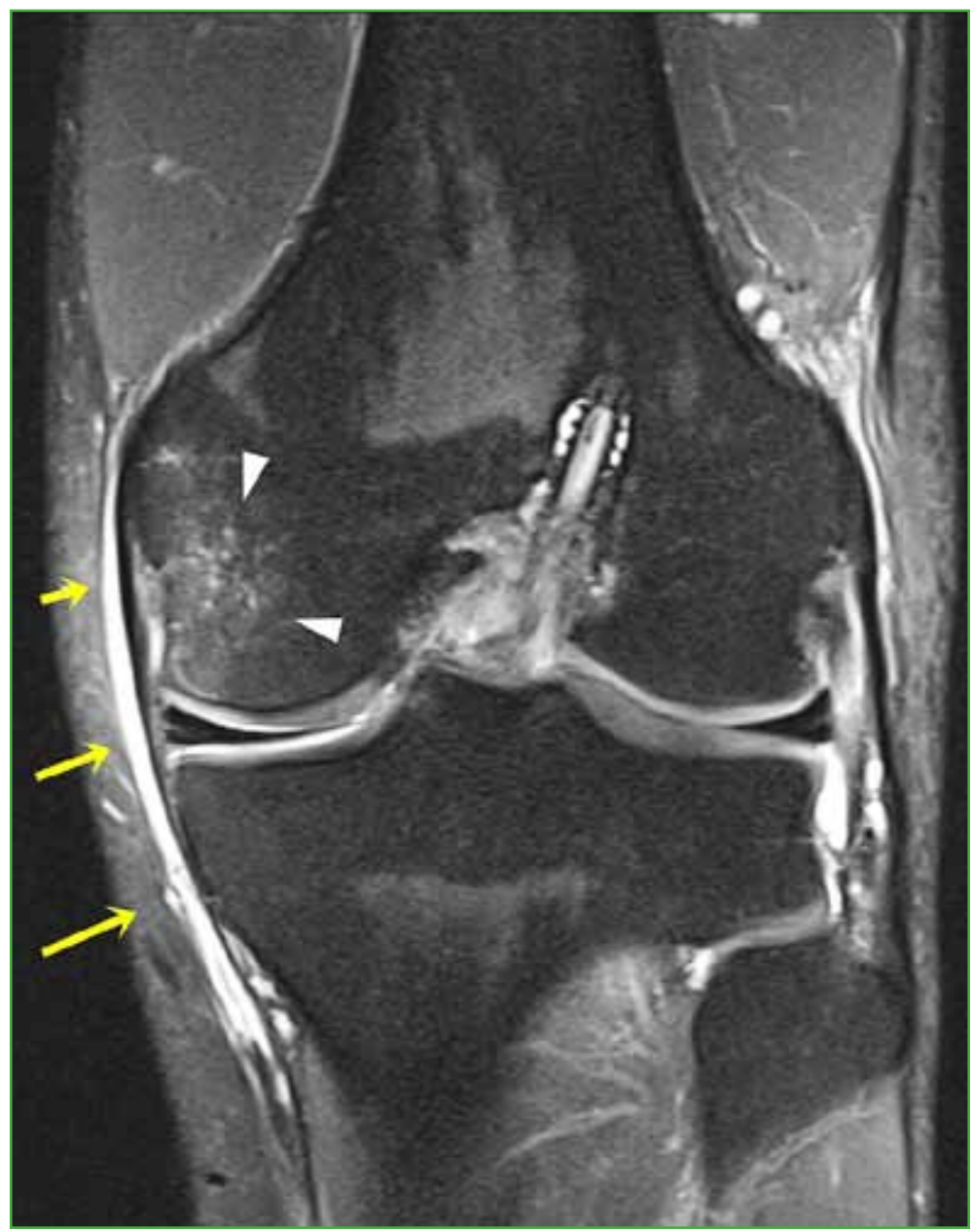

Figura 5. Resonancia magnética de rodilla en el plano coronal, con secuencia DP con supresión grasa (3673/34). Edema periligamentario (flechas) en relación con el colateral interno, con continuidad ligamentaria (lesión grado I), como lesión asociada y edema contusivo en la médula ósea del cóndilo femoral (puntas de flecha).

Conflicto de intereses: Los autores no declaran conflictos de intereses.

ORCID iD de G. Schneebeli: https://orcid.org/0000-0003-4712-1304

ORCID iD de A. Lamanna: hitps://orcid. org/0000-0003-1061-4981 